\title{
1 Phage-resistant bacteria reveal a role for potassium in root colonization
}

2 Elhanan Tzipilevich ${ }^{1,2}$ and Philip N. Benfey ${ }^{1,2^{*}}$

3

$4 \quad{ }^{1}$ Howard Hughes Medical Institute, Duke University, Durham, NC 27708, USA

$5 \quad{ }^{2}$ Department of Biology, Duke University, Durham, NC 27708, USA

$6 \quad *$ Correspondence to: philip.benfey@duke.edu

8 Abstract

9 Bacteriophage predation is an important factor in bacterial community dynamics and evolution.

10 Phage-bacteria interaction has mainly been studied in lab cultures, while dynamics in natural

11 habitats, and especially in the plant root niche are underexplored. To better understand this process,

12 we characterized infection of the soil bacterium B. subtilis NCBI 3610 by the lytic phage SPO1

13 during growth in LB medium and compared it to root colonization. Resistance in vitro was

14 primarily through modification of the phage receptor. However, this type of resistance reduced the

15 ability to colonize the root. From a line that survived phage infection while retaining the ability to

16 colonize the root, we identified a plant-specific phage resistance mechanism involving potassium

$17(\mathrm{~K}+)$ ion influx modulation and enhanced biofilm formation. 


\section{Introduction}

3 Plant roots are associated with diverse bacteria in the soil (Lundberg et al., 2012), which can affect

4 many aspects of plant life including root architecture (Verbon and Liberman, 2016), nutrient

5 acquisition (Hacquard et al., 2015) and disease state (Lugtenberg and Kamilova, 2009; Verbon

6 and Liberman, 2016). The root rhizosphere, i.e. the area close to the root surface, is enriched with

7 specific bacterial taxa in comparison to bulk soil. This unique microbial composition is determined

8 by the soil surrounding the plant root and its pre-existing bacterial diversity (Finkel et al., 2019;

9 Peiffer et al., 2013), plant genotype (Wagner et al., 2016), as well as the interaction with other

10 bacteria (Finkel et al., 2020), and with phage (Koskella and Taylor, 2018). Although a large body

11 of research has been conducted to characterize each of these factors, the whole picture, and

12 especially the role of phage in bacterial root colonization, is far from complete.

Phage are viruses that infect and kill bacteria (Koskella and Brockhurst, 2014; Salmond

14 and Fineran, 2015). As bacterial predators, they influence bacterial community dynamics through

15 elimination of their sensitive hosts. Bacteria, in turn, respond by rapid evolution of phage

16 resistance (Labrie et al., 2010). In addition to influencing bacterial interaction with phage, newly

17 acquired resistance (Koskella and Brockhurst, 2014; Rodriguez-Valera et al., 2009) can also cause

18 changes in colony morphology (Buckling and Rainey, 2002), genome wide mutation rate (Pal et

19 al., 2007) and lateral spread of genetic material (Haaber et al., 2016). In recent years, insights have

20 been gained into how phage-bacteria interactions affect bacterial growth in ocean (Paul and

21 Sullivan, 2005), and mammalian gut ecosystems (Shkoporov and Hill, 2019). However, little is

22 known about how the effects of phage-bacteria interactions in other ecosystems, especially in soil

23 and the root rhizosphere (Pratama and van Elsas, 2018). 
To address this question, we utilized Bacillus subtilis strain NCIB 3610 (henceforth

2 B.subtilis) (Branda et al., 2001) and its cognate lytic phage SPO1 (Stewart et al., 2009) to explore

3 their interaction during root colonization of the plant model system Arabidopsis thaliana. B.

4 subtilis is a Gram-positive, spore forming bacteria isolated from soil, and is able to colonize plant

5 roots (Chen et al., 2012). Root colonization by $B$. subtilis is mediated by formation of a biofilm on

6 the root (Beauregard et al., 2013). Biofilms are bacterial communities encased in an extracellular

7 matrix. The $B$. subtilis matrix is mainly composed of sugar polymers, encoded by the eps operon,

8 and protein fibers encoded by tapA-sip $W$-tas $A$ operon (Vlamakis et al., 2013). B. subtilis defective

9 in biofilm formation exhibit severe defects in root colonization (Beauregard et al., 2013). The

10 phage SPO1 is a lytic phage, representing a large and diverse group of Myoviridae bacteriophages,

11 harboring a long contractile tail. SPO1 phage exhibit a complex infection cycle, involving the

12 subversion of the host transcription machinery for its own use (Hoet et al., 1992). SPO1 utilize the

13 wall teichoic acid polymers (WTA) as a receptor to invade B. subtillis cells (Habusha et al., 2019).

14 WTA are long sugar polymers that are incorporated into the cell wall and membrane of $B$. subtillis

15 and other Gram-positive bacteria (Brown et al., 2013). SPO1 bind these polymers when they are

16 decorated by glucose moieties (gWTA). Comparison of phage-bacteria evolution upon infection

17 in LB medium and during root colonization revealed that phage infection in vitro and in planta

18 exhibits different evolutionary trajectories. Characterization of bacteria resistant to phage infection

19 during root colonization led to the identification of a plant-specific phage resistance mechanism

20 through modulation of potassium $\left(\mathrm{K}^{+}\right)$ion influx, and enhanced biofilm formation. Furthermore,

21 we show that potassium serves as a stimulator of root colonization among diverse bacilli species. 


\section{$1 \quad$ Results}

\section{Loss of phage receptor results in a fitness cost for root colonization}

4 To explore phage-bacteria interactions during root colonization we inoculated the roots of $A$.

5 thaliana with $B$. subtillis 3610 bacteria together with SPO1 phage at either high (phage:bacteria

6 1:1), or low (phage:bacteria 1:10) multiplicity of infection (MOI). Measuring bacterial

7 colonization (CFU colony forming units) after 48 hours, revealed a reduction in root colonization

8 of $\sim 95 \%$ at an MOI of 1 , and $\sim 90 \%$ reduction at an MOI of 0.1 (Figure 1A) indicating that SPO1

9 can efficiently infect and kill its host bacteria during root colonization. Because selection pressure

10 by phage drives bacterial counter adaptation (Buckling and Brockhurst, 2012) we isolated 300

11 bacteria [screen 1] that survived phage infection on the root and re-streaked them on agar plates

12 containing SPO1 phage. Only 20 in planta survivors were resistant to phage infection in vitro. In

13 contrast, $100 \%$ of 70 bacteria isolated after surviving phage infection in LB medium, became

14 immune to further infection. Twenty randomly selected in vitro survivors became phage resistant

15 through loss of the phage receptor, as judged by a lack of con $\mathrm{A}_{488}$ staining, a lectin that binds

16 specifically glycosylated WTA (gWTA) (Figure 1B) [see also (Habusha et al., 2019)]. Of the 20

17 SPO1 resistant bacteria isolated from the plant all but one $(\mathrm{m} 28)$ had lost their ability to re-colonize

18 the root (Figure 1C). Nineteen of these isolates concomitantly lost their con $\mathrm{A}_{488}$ staining (Figure

$19 \mathrm{~S} 1 \mathrm{~A})$. One of the isolates, m28, was completely phage resistant in-vitro (Figure S1B), but still

20 exhibited faint con $\mathrm{A}_{488}$ staining (Figure S1A and S1C), and partial sensitivity when infected on

21 roots (Figure 2A). The correlation between SPO1 sensitivity and root colonization ability suggests

22 that gWTA is important for efficient root colonization. To test this hypothesis, we inoculated roots

23 with $\triangle \operatorname{tag} E$ bacteria, which lack gWTA (Allison et al., 2011), and found a significant reduction in 
1 root colonization (Figure 1D-1E). Because biofilm formation has been shown to be necessary for

2 root colonization by $B$. subtilis (Banda et al., 2019), we tested the ability of $\Delta \operatorname{tagE}$ bacteria to form

3 a biofilm in-vitro. $\Delta \operatorname{tag} E$ cells exhibit normal biofilm formation both on agar plates and liquid

4 medium (Figure 1F). Of note, gWTA is required for nasal epithelium colonization by

5 Staphylococcus aureus (Winstel et al., 2015). Our results suggest that gWTA in B. subtilis is

6 similarly important for plant surface adhesion, irrespective of biofilm formation. 
bioRxiv preprint doi: https://doi.org/10.1101/2021.05.12.443821; this version posted May 12, 2021. The copyright holder for this preprint (which

was not certified by peer review) is the author/funder, who has granted bioRxiv a license to display the preprint in perpetuity. It is made available under aCC-BY-NC-ND 4.0 International license.

\section{Figure 1}
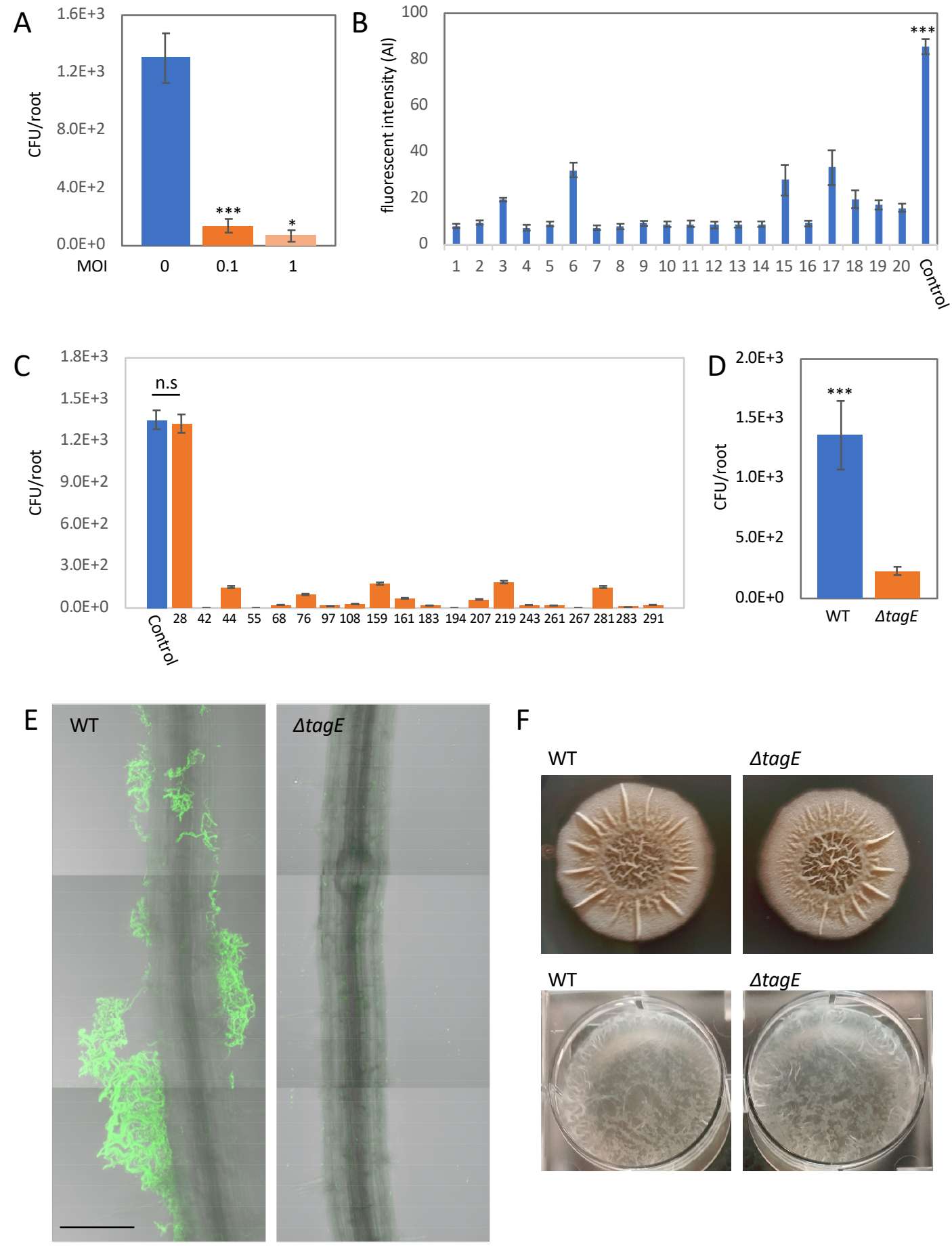

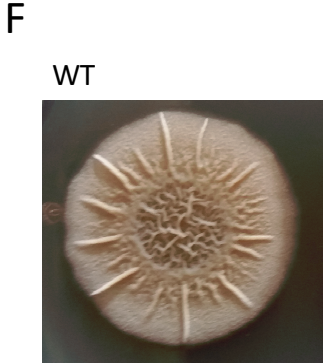

WT

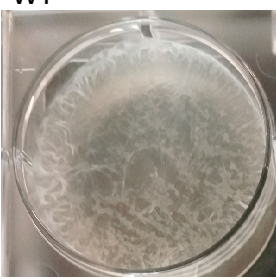

$\triangle \operatorname{tag} E$

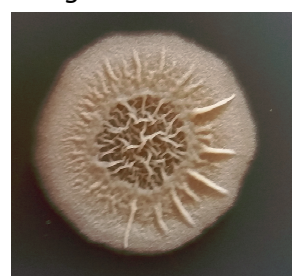

$\triangle \operatorname{tag} E$

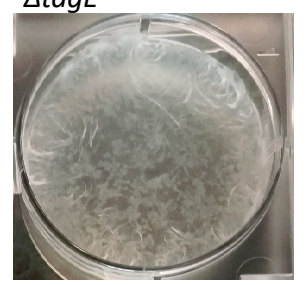




\section{Figure 1. SPO1 phage receptor is necessary for bacterial root adhesion}

2 (A) Seedlings were inoculated with B. subtilis 3610 together with SPO1 phage, at either high (phage : bacteria 1:1),

3 low (phages : bacteria 1:10) multiplicity of infection $(\mathrm{MOI})$, or no phage $(\mathrm{MOI}=0)$ for $48 \mathrm{hrs}$, on agar plates, and the

4 number of colonizing bacteria was counted. Shown are averages and SD of 2 independent experiments with $\mathrm{n} \geq 3$ for

5 each, $*=P<0.05, * * *=P<0.005$.

6 (B) 20 randomly selected bacterial colonies that survived SPO1 infection were stained with conA488 and observed

7 under a compound microscope. Shown are average and SD fluorescent intensity values of 10 bacteria from each of

8 the colonies.

9 (C) 20 isolated SPO1 resistant bacteria were inoculated on seedlings, grown for $48 \mathrm{hrs}$ and the number of colonizing

10 bacteria counted. Shown are averages and SD with $\mathrm{n} \geq 3, * * *=P<0.005$.

11 (D) Seedlings were inoculated with either WT or $\triangle \operatorname{tag} E$ bacteria for $48 \mathrm{hrs}$, and the number of colonizing bacteria was

12 counted. Shown are averages and SD of 2 independent experiments with $\mathrm{n} \geq 3$ for each, $* * *=P<0.005$.

13 (E) Seedlings were inoculated with either WT or $\Delta t a g E$ bacteria expressing GFP (amyE::P $\mathrm{P}_{r n E}$-gfp) for 48 hrs on agar

14 plates. Shown are representative overlay 200x confocal images of DIC (root) and GFP fluorescence (bacteria). Scale

15 bar, $50 \mu \mathrm{m}$.

16 (F) WT and $\triangle \operatorname{tag} E$ bacteria were inoculated into MSgg media on agar plates (upper) or liquid media (lower). Shown

17 are representative biofilm images.

\section{Bacteria evolve a root-specific phage resistance mechanism}

20 Our results indicate that loss of the phage receptor results in a fitness cost to bacteria during root

21 colonization. To identify alternative pathways utilized by bacteria to resist phage infection during

22 root colonization, we isolated bacteria that survived phage infection on the root (from screen 1)

23 and infected them with SPO1 during root colonization (screen 2). Most of the bacteria exhibited

24 phage sensitivity similar to the parental bacteria. However, of 100 bacterial strains tested, we found

254 that survived SPO1 infection on roots better than WT cells (Figure 2A). To explore the

26 mechanism of phage survival, we sequenced the genomes of $\mathrm{m} 5, \mathrm{~m} 11, \mathrm{~m} 54$ and $\mathrm{m} 93$, the 4 bacteria 
1 isolated during screen 2 along with m28 isolated from screen 1 . Table 1 presents the mutations in

2 each of the bacteria.

3 Table 1

\begin{tabular}{|c|c|}
\hline Bacterial strain & Mutation \\
\hline $\mathrm{m} 5$ & $\begin{array}{c}\text { Missense mutation in KtrC } \\
\text { P189T }\end{array}$ \\
\hline $\mathrm{m} 11$ & Mutations in YwbO promoter \\
\hline $\mathrm{m} 28$ & Missense mutation GtaB Y170S \\
\hline $\mathrm{m} 54$ & $\begin{array}{c}\text { Missense mutations in } \\
\text { YwrK T334S and CdaA F97L }\end{array}$ \\
\hline $\mathrm{m} 93$ & $\begin{array}{c}\text { Frame shift in tagE T1013 } \\
\text { leading to premature stop } \\
\text { codon }\end{array}$ \\
\hline
\end{tabular}

M28 and m93 harbor mutations in gtaB and tagE, genes involved in the WTA glycosylation pathway (figure 2B and figure S1C) (Brown et al., 2013). Interestingly, m11 and m54 don't have mutations in genes previously implicated in WTA glycosylation, but nonetheless exhibited complete (m54) and partial (m11) loss of conA 488 staining (figure 2B and figure $\mathrm{S} 1 \mathrm{C}$ ). m11, m54 and m93 exhibited phage resistance in vitro (figure S1B).

12 MOI (1-0.1) (Figure 2C-2D), phage sensitivity in vitro, and conA488 staining similar to WT (Figure

$132 \mathrm{~B}, 2 \mathrm{E}$ and figure $\mathrm{S} 2 \mathrm{~B}$ ) indicating that it harbors a root-specific phage resistance mechanism. The

14 m5 mutant also exhibits enhanced resistance to infection by SPP1, a lytic phage from a different

15 bacteriophage family (siphoviridae), (Figure 2F), indicating that its resistance mechanism is not

16 phage-family specific. M5 harbors a single point mutation in the $k t r C$ gene, encoding a low affinity

17 potassium channel. This missense mutation changes Proline 189 into Threonine (KtrC P189T) and

18 resides in a conserved RCK domain, known to bind the regulatory molecule ci-d-AMP (Corrigan

19 et al., 2013; Rocha et al., 2019). ci-d-AMP negatively regulates potassium uptake (Gundlach et

20 al., 2019). We hypothesized that KtrC P189T is a gain of function mutation, affecting the

21 regulation of potassium uptake. 


\section{Figure 2}
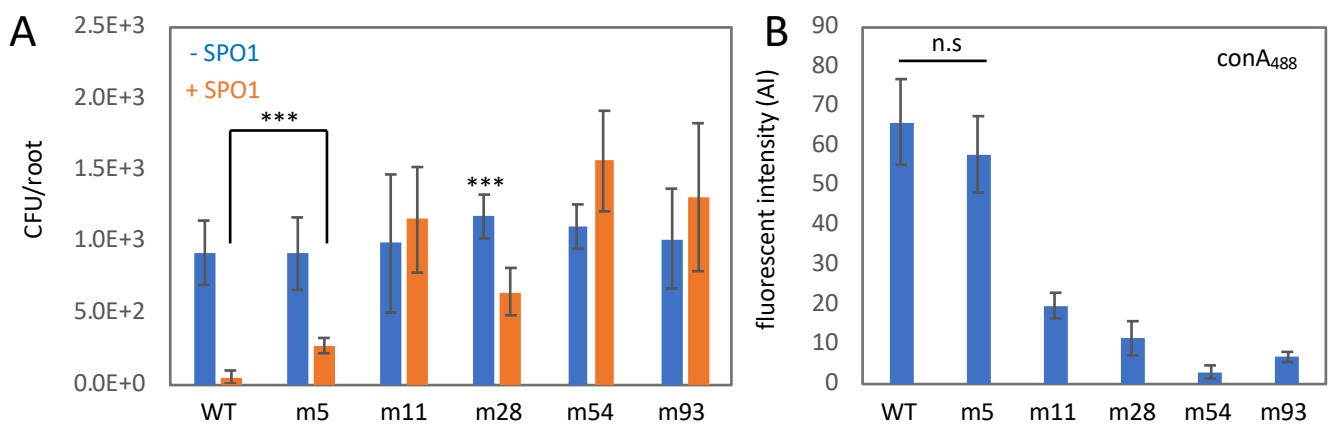

C
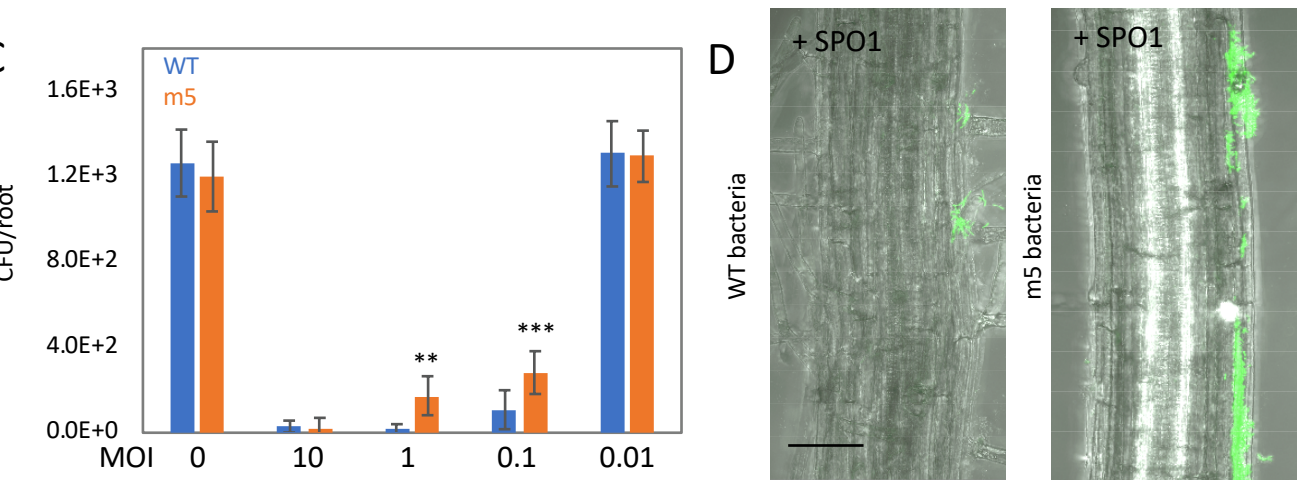

E

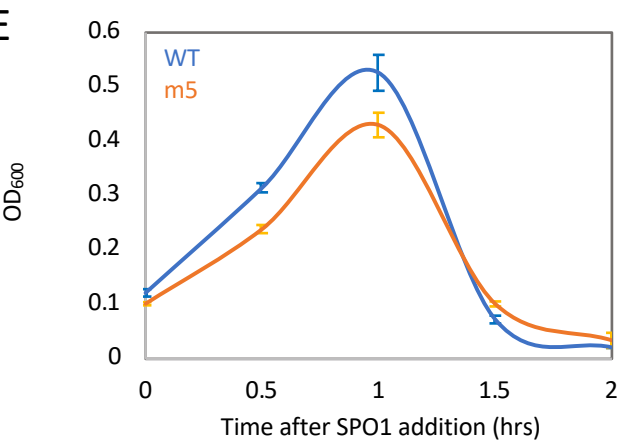

$\mathrm{F}$

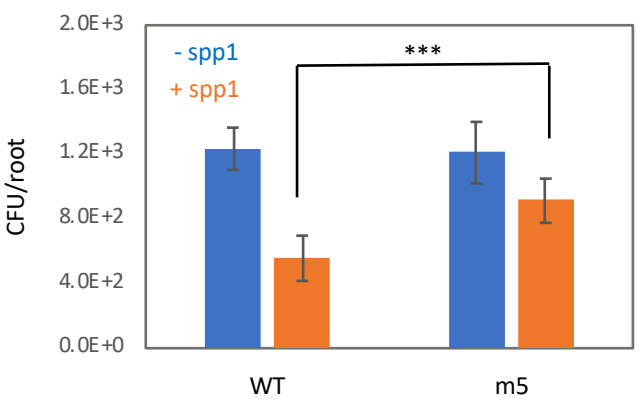




\section{Figure 2. A root-specific SPO1 resistance mechanism}

2 (A) Seedlings were inoculated with the indicated bacterial strains, with or without SPO1 addition, for 48 hrs on agar

3 plates, and the number of colonizing bacteria was counted. Shown are averages and SD of 2 independent experiments

4 with $\mathrm{n} \geq 3$ for each, $* *=P<0.01$.

5 (B) Bacterial strains were stained with con $\mathrm{A}_{488}$ and observed under the microscope. Shown are average and SD of

6 fluorescence intensity values of 10 bacteria from each colony.

7 (C) Seedlings were inoculated with either WT or m5 bacteria, with the indicated phage MOI, for 48 hrs on agar plates,

8 and the number of colonizing bacteria counted. Shown are averages and SD of 2 independent experiments with $\mathrm{n} \geq 3$

9 for each, $* * *=P<0.005$.

10 (D) Seedlings were inoculated with either WT or m5 bacteria expressing GFP (amyE::P $\mathrm{P}_{r n E}$-gfp), in the presence of

11 SPO1, for $48 \mathrm{hrs}$ on agar plates. Shown are representative overlay 200x confocal images of DIC (root) and GFP

12 fluorescence (bacteria). Scale bars $20 \mu \mathrm{m}$.

13 (E) WT and m5 bacteria were infected with SPO1 in LB media, and OD $_{600}$ was followed. Shown are averages and $14 \mathrm{SD}, \mathrm{n}=3$.

15 (F) Seedlings were inoculated with either WT or m5 bacteria, with or without spp1 phages for 48 hrs on agar plates,

16 and the number of colonizing bacteria was counted. Shown are averages and SD of 2 independent experiments with $\mathrm{n}$

$17 \geq 3$ for each, $* * *=P<0.005$.

19 Potassium enhances root colonization and phage tolerance through modulation of biofilm

\section{0 formation}

21 Several potassium channels are encoded in the B. subtillis genome: ktrAB and kimA encode high

22 affinity channels (Gundlach et al., 2017; Holtmann et al., 2003) while the ktrCD operon encodes

23 a low affinity channel (Holtmann et al., 2003). To understand the effect of the KtrC P189T

24 mutation and potassium uptake on bacterial root colonization, we examined the colonization

25 efficiency of bacteria lacking these channels. While $\Delta k \operatorname{tr} C$ and $\Delta k i m A$ colonize the root with

26 similar efficiency to WT bacteria (Figure $3 \mathrm{~A}$ ), $\Delta k t r A$ bacteria exhibited reduced root colonization 
1 (Figure 3A). The KtrC P189T mutation is able to restore the colonization of $\Delta k \operatorname{tr} A$ bacteria (Figure

$23 \mathrm{~A}$ ), suggesting that this mutation enhances potassium uptake through the KtrC channel. Growing

3 plants on media with different levels of potassium revealed a positive correlation between

4 potassium concentration and root colonization by WT bacteria (Figure 3B), with the effect

5 plateauing at $10 \mathrm{mM}$. Similarly, root colonization on 0.25 MS plates, with addition of $5 \mathrm{mM}$

6 potassium $(\mathrm{KCl})$ (equal to total of $\sim 10 \mathrm{mM}$ ) indicated a positive effect of potassium on root

7 colonization (Figure 3C). Stimulation of root colonization was specific to potassium ions, as

8 neither sodium nor nitrogen (Fig S2A) had a similar effect. Consistent with the KtrC P189T

9 mutation affecting phage infection through increased potassium uptake, addition of potassium was

10 sufficient to enhance survival of WT cells upon phage infection (Figure 3C-3D).

11 It has been previously shown that $B$. subtilis bacteria sense potassium influx through the

12 cell membrane, utilizing $\mathrm{KinC}$ and $\mathrm{KinB}$ protein kinases to induce biofilm formation genes and

13 sliding motility, respectively, (Grau et al., 2015; Lopez et al., 2009). Both biofilm formation and

14 sliding motility play an important role during root colonization (Bais et al., 2004; Beauregard et

15 al., 2013). We found that $\mathrm{m} 5 \Delta k i n C$ bacteria, but not m5 $\Delta$ kinB lost SPO1 resistance (Figure 3E).

16 Addition of potassium to $\Delta$ kinC bacteria failed to stimulate phage resistance (Figure S2C). KinC

17 activation induces a phosphorylation cascade that culminates in induction of biofilm matrix genes

18 (Lopez et al., 2009). Disruption of the biofilm matrix operons epsA-O and tapA-sipW-tas $A$

19 abolished the effect of potassium on root colonization (Figure S2C). Interestingly disruption of the

$20 \operatorname{tap} A$-sip $W$-tas $A$ operon, but not eps $A-O$, reduced the phage resistance phenotype of m5 cells

21 (Figure 3F-3G), suggesting that an increase in protein fiber component is responsible for the phage

22 tolerance effect of increased potassium influx. Thus, our analysis revealed a root-specific phage 
1 adaptation mechanism that works through enhanced potassium influx by stimulating biofilm matrix formation.

Figure 3
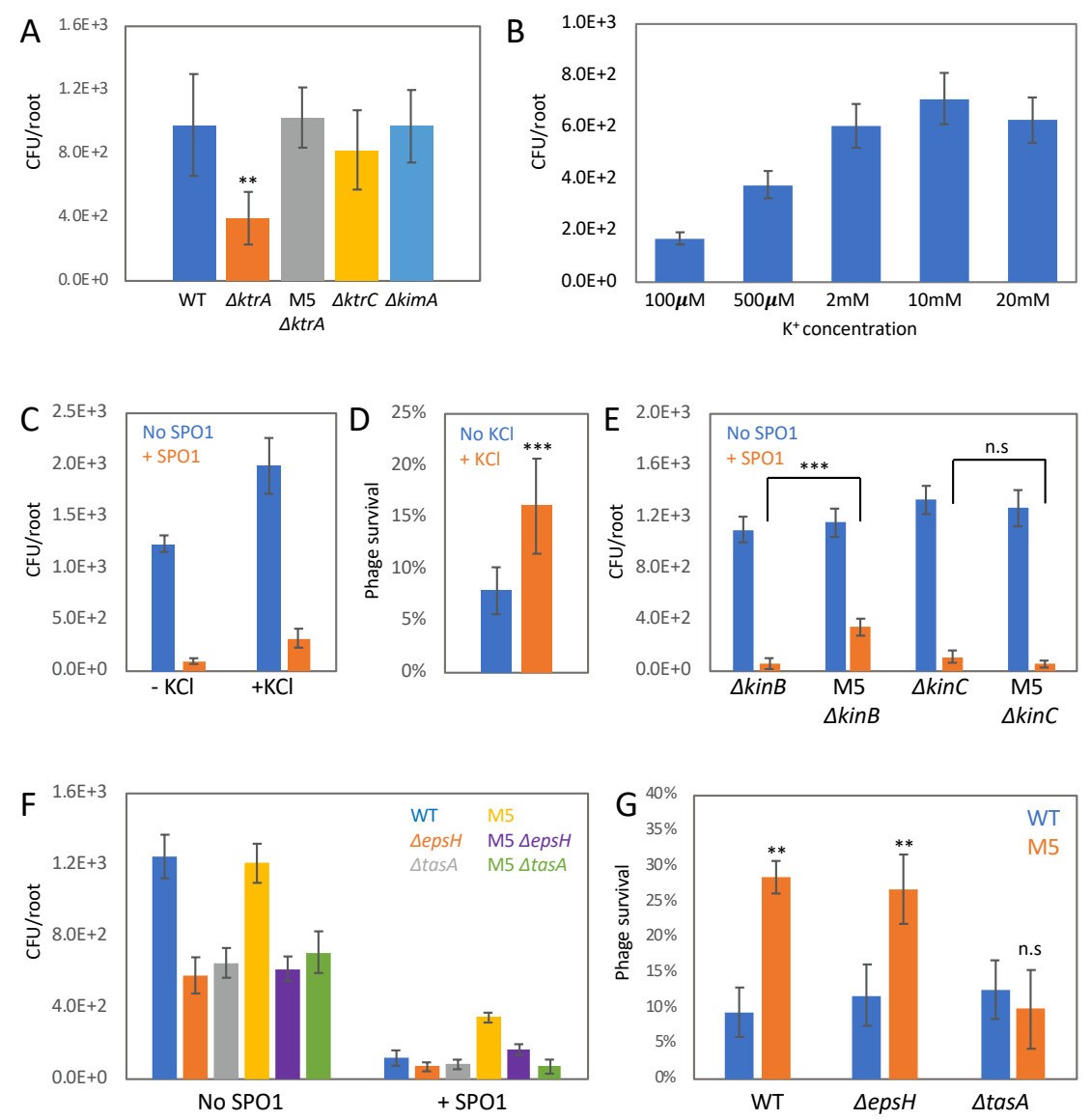

4 Figure 3. Potassium modulates $B$. subtillis root colonization and phage resistance through biofilm formation.

5 (A) Seedlings were inoculated with the indicated bacterial strains for $48 \mathrm{hrs}$ on agar plates, and the number of 6 colonizing bacteria was counted. Shown are averages and $\mathrm{SD}$ of 2 independent experiments with $\mathrm{n} \geq 3$ for each, ** $=$ $P<0.01$. 
1 (B) Seedlings were inoculated with WT B. subtillis on MS agar plates supplemented with the indicated potassium

2 concentration, for $48 \mathrm{hrs}$, and the number of colonizing bacteria was counted. Shown are averages and SD of 2

3 independent experiments with $\mathrm{n} \geq 3$ for each.

4 (C-D) Seedlings were inoculated with WT B. subtillis, with or without SPO1 addition, for 48 hrs on 0.25MS agar

5 plates, in the presence or absence of $5 \mathrm{mM} \mathrm{KCl}$, and the number of colonizing bacteria was counted. Shown are

6 averages and SD CFU (C), and the percentage of SPO1 survival (D), from 2 independent experiments with $\mathrm{n} \geq 3$ for

7 each, $* *=P<0.01$.

8 (E) Seedlings were inoculated with the indicated bacterial strains, with or without SPO1 addition, for 48 hrs on agar

9 plates, and the number of colonizing bacteria was counted. Shown are averages and SD of 2 independent experiments

10 with $\mathrm{n} \geq 3$ for each, $* *=P<0.01$.

11 (F-G) Seedlings were inoculated with the indicated bacterial strains, with or without SPO1 addition, for $48 \mathrm{hrs}$ on

12 agar plates, in the presence or absence of $5 \mathrm{mM} \mathrm{KCl}$, and the number of colonizing bacteria was counted. Shown are 13 averages and SD CFU (F), and the percentage of SPO1 survival (G), from 2 independent experiments with $\mathrm{n} \geq 3$ for 14 each, $* *=P<0.01$.

16 To further characterize the role of biofilm matrix formation in phage tolerance, we monitored

17 SPO1 infection during biofilm formation in vitro (Branda et al., 2001). Measurement of biofilm

18 diameter on MSgg agar plates revealed significant reduction in colony diameter on plates

19 containing SPO1 phage (Figure 4A). Of note, $\Delta k t r A$ cells, although able to form normal biofilm in

20 the absence of phage, exhibit a significant decrease in biofilm diameter in the presence of phage

21 in comparison to WT infected cells (Figure 4A-4B). Similar to what was observed in plants, the

22 KtrC P189T mutation was able to compensate for the increased sensitivity of $\Delta k t r A$ cells (Figure

23 4A-4B). Thus, our in vitro analysis, provides further support for the hypothesis that potassium

24 influx modulates biofilm formation to enhance phage resistance. Equivalent results were obtained

25 for pellicle biofilm formation on liquid MSgg medium (Figure S3), where enhanced potassium

26 influx in m5 bacteria, or addition of extra potassium to the medium of WT bacteria, increased the 
1 chance of surviving SPO1 infection, while decreased influx, due to the $\Delta k t r A$ mutation, increased

2 phage sensitivity.

3

\section{Figure 4}
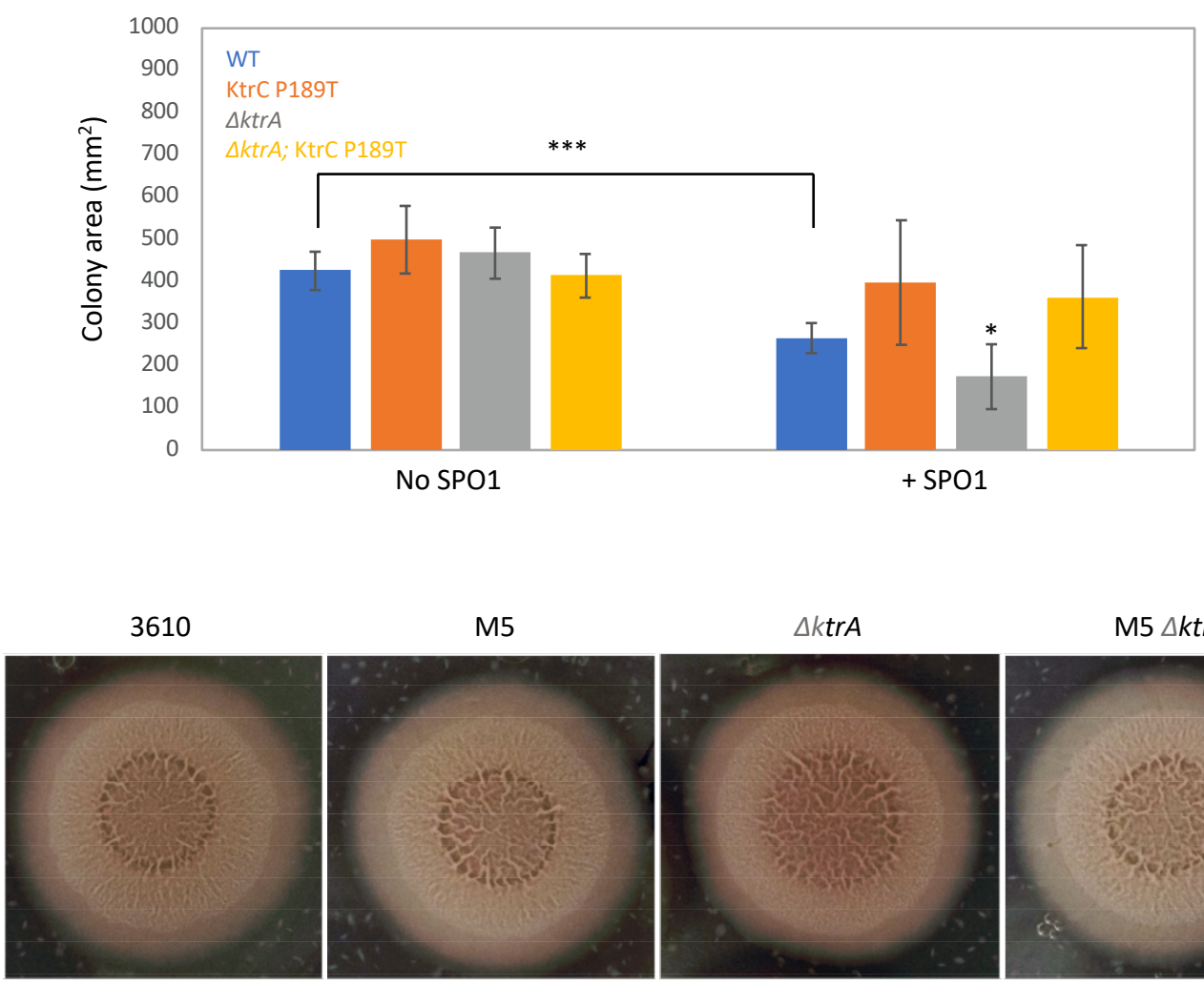

M5

$\triangle k t r A$

M5 $\Delta k t r A$
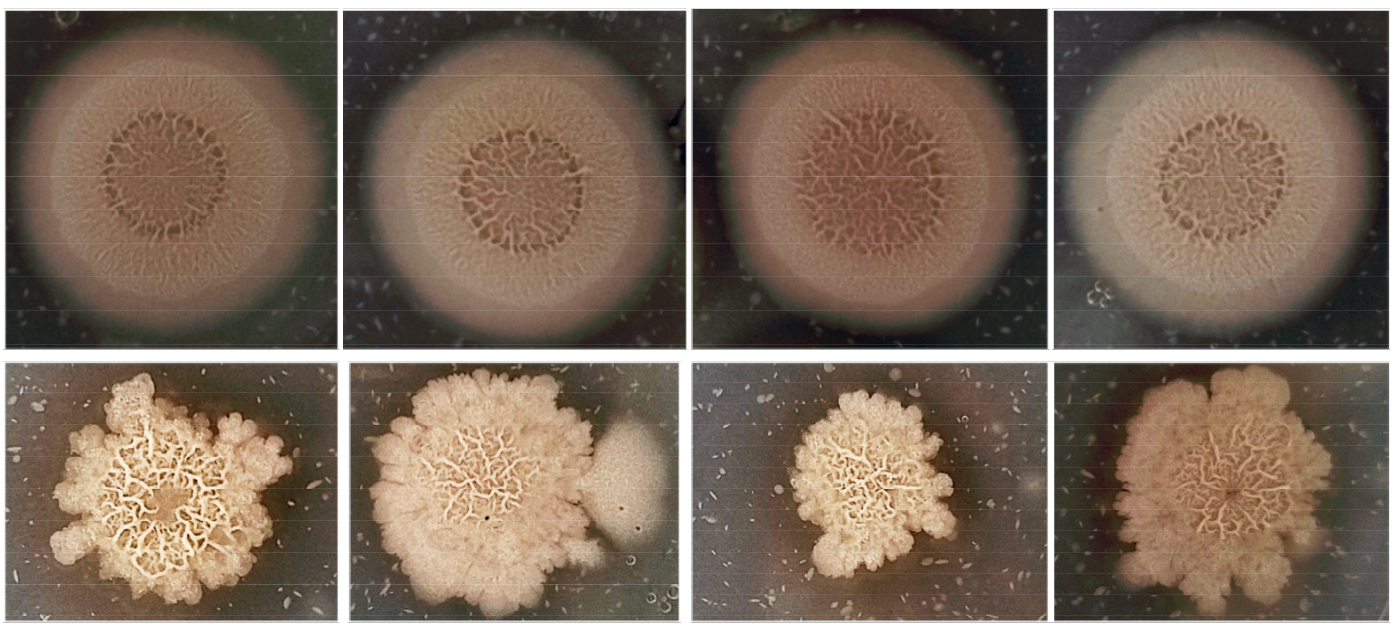

4

5

6 Figure 4. Potassium modulates phage resistance during biofilm formation in-vitro.

7 (A) The indicated bacterial strain were inoculated onto MSgg agar plates with or without SPO1 addition for 48 hrs,

8 and colony area measured. Shown are averages and SD of $\mathrm{n}=6 .{ }^{*}=P<0.05$. 
1 (B) Shown are representative images for the experiment described in (A) with (lower panel), or without (upper panel)

$2 \quad$ SPO1 addition.

3

4 Potassium enhances root colonization by diverse bacilli species.

5 To determine if potassium is able to enhance colonization by other bacilli species we analyzed its

6 effect on B.valezensis fzb42 a plant-associated bacterium (Fan et al., 2018), shown to enhance plant

7 health through growth stimulation and pathogen inhibition. We found that potassium enhances

8 root colonization of B.valezensis fzb42 (Figure 5A), and this phenomenon was abolished in

9 B.valezensis fzb42 $\Delta$ kinC cells (Figure 5B). A similar phenomenon was observed for B.subtilis

10 GB03 and B.pumilus SE34, two other plant growth promoting bacteria (Figure 5A). Thus,

11 potassium serves as a wide-spread signal, stimulating root colonization by diverse bacilli species.

12 B.valezensis fzb42 inhibits the growth of the plant fungal pathogen Rhizoctonia solani (Krober et

13 al., 2014), raising the possibility that simply adding potassium to the growth media could enhance

14 B.valezensis $f z b 42$ colonization and fungal protection. Indeed, potassium enhanced plant survival

15 when inoculated with Rhizoctonia solani, in the presence of B.valezensis fzb42 (Figure 5C), and

16 this effect was abolished in $\Delta k i n C$ cells, which are unable to sense potassium influx (Figure 5C). 


\section{Figure 5}
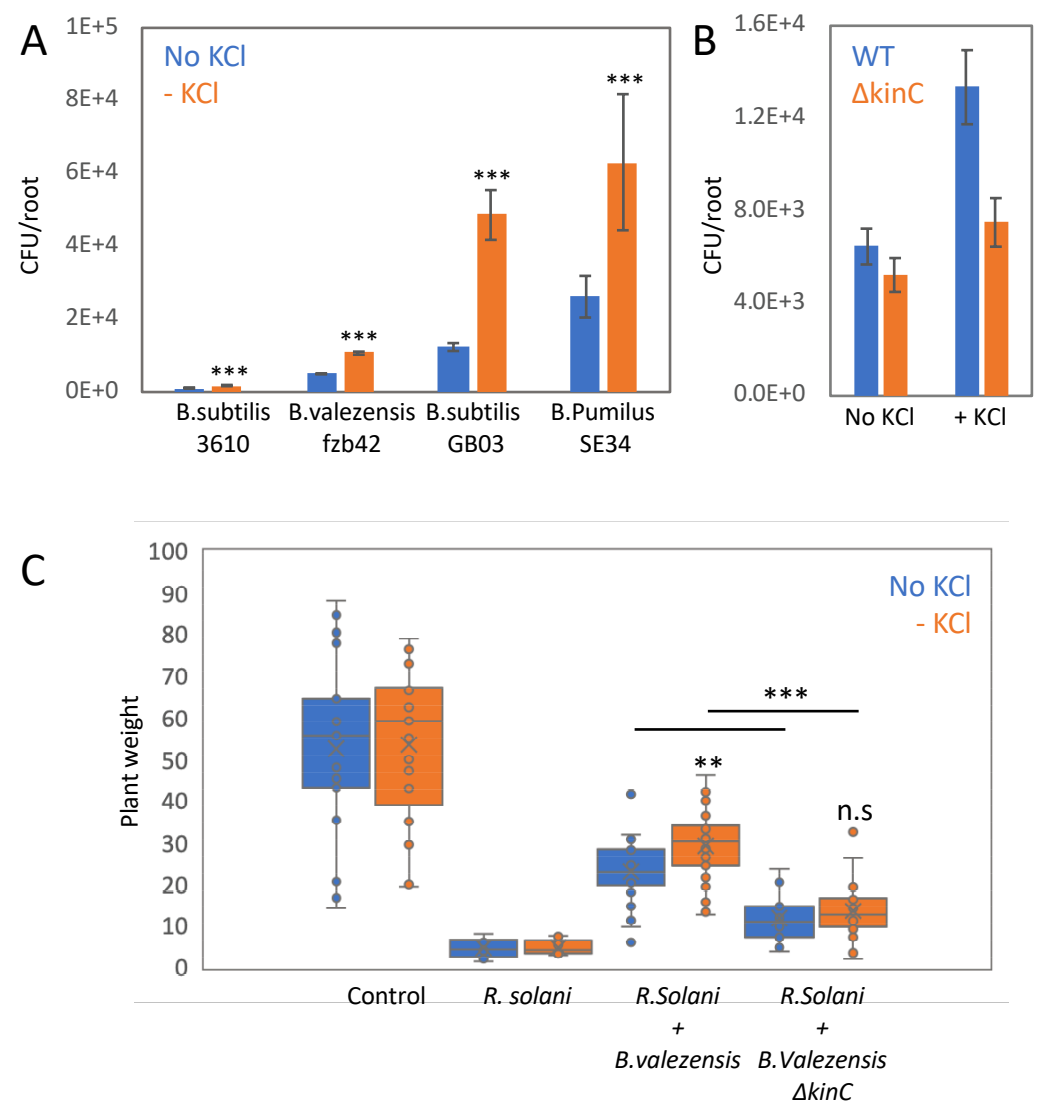

2 Figure 5. Potassium modulates root colonization by diverse bacilli species.

3 (A) Seedlings were inoculated with the indicated bacterial species,for $48 \mathrm{hrs}$ on $0.25 \mathrm{MS}$ agar plates, in the presence

4 or absence of $5 \mathrm{mM} \mathrm{KCl}$, and the number of colonizing bacteria was counted. Shown are averages and SD of 2

5 independent experiments with $\mathrm{n} \geq 3$ for each, $* *=P<0.01$.

6 (B) Seedlings were inoculated with either WT or $\Delta$ kinC B. valezensis fzb42 bacteria, for $48 \mathrm{hrs}$ on $0.25 \mathrm{MS}$ agar plates,

7 in the presence or absence of $5 \mathrm{mM} \mathrm{KCl}$, and the number of colonizing bacteria was counted. Shown are averages and

8 SD of 2 independent experiments with $\mathrm{n} \geq 3$ for each, $* *=P<0.01$.

9 (C) Seedlings were inoculated with either WT or $\Delta$ kinC B. valezensis fzb42 bacteria, for $48 \mathrm{hrs}$ on $0.25 \mathrm{MS}$ agar plates, in the presence or absence of $5 \mathrm{mM} \mathrm{KCl}$. Next, plates were inoculated with $R$. solani and incubated for an additional 
bioRxiv preprint doi: https://doi.org/10.1101/2021.05.12.443821; this version posted May 12, 2021. The copyright holder for this preprint (which

was not certified by peer review) is the author/funder, who has granted bioRxiv a license to display the preprint in perpetuity. It is made available under aCC-BY-NC-ND 4.0 International license.

17 days and plant weight was measured. Untreated plants (neither bacteria, nor fungi) were used as control. Shown are

2 averages and SD, $\mathrm{n} \geq 20 . * *=P<0.01, * * *=P<0.005$.

3 


\section{Discussion}

3 Phage infection has been extensively characterized in lab cultures. Recent work revealed that

4 phage-bacteria interaction in natural environments can differ significantly from that observed in

5 the lab (Diaz-Munoz and Koskella, 2014) due to the fitness constraints encountered by bacteria in

6 their natural environment. This can impede the evolution of phage receptors, the main resistance

7 pathway observed in the lab (Westra et al., 2015). We found that gWTA, the SPO1 phage receptor

8 is essential for root adhesion, thus receptor modification has a fitness cost in the root environment.

9 Of note, it has been shown that gWTA is essential for adhesion of Staphylococcus aureus to the

10 nasal epithelium (Winstel et al., 2015), while gWTA also serves as phage receptor for several

11 S.aureus infecting phages (Moller et al., 2019). It will be interesting to determine if phage bacteria

12 evolution is constrained in this niche as well.

While evolution of receptor modification is not favored, we found that bacteria in the root

14 adapt to phage infection through evolution of enhanced biofilm formation. Consistent with

15 previous in-vitro work (Lopez et al., 2009), we show that during plant colonization, altering

16 potassium efflux through $\mathrm{KtrCD}$ channels enhances $B$. subtillis biofilm formation, and thus

17 promotes survival upon phage infection. Our results indicate that protein fiber density, encoded by

18 the $\operatorname{tap} A-\operatorname{sip} W$-tas $A$ operon, is the main determinant of SPO1 resistance. Interestingly, it has been

19 shown that curli protein fibers are important for $\mathrm{T} 7$ resistance in a biofilm of E. coli bacteria

20 (Vidakovic et al., 2018). Phage-bacteria interaction in biofilm is an emerging area of research

21 (Hansen et al., 2019), and much remains to be learned about the interaction dynamic in this

22 important bacterial niche. In our screen for in planta phage resistant bacteria we found 4 bacteria

23 of 100 with genetically-inherited enhanced phage resistance. This suggests that $96 \%$ of the bacteria 
1 survived infection in a non-genetic manner. It would be interesting to determine how non-genetic

2 mechanisms enable bacteria to survive phage infection.

3 Potassium is an essential macronutrient for bacteria and plants. Unlike nitrogen and phosphate, it

4 is not incorporated into cellular macromolecules, but remains a soluble ion (Amtmann and

5 Armengaud, 2009). Potassium is involved in the regulation of many processes, including osmotic

6 adaptation, membrane potential, phloem transport, regulation of metabolic enzymes, and biotic

7 and abiotic stress responses. Potassium, together with nitrogen and phosphate, are the three main

8 ions consumed by plants and are heavily utilized for fertilization in modern agriculture. (Sustr et

9 al., 2019). The effect of nitrogen and phosphorous on root microbial communities has been

10 characterized (Castrillo et al., 2017; Finkel et al., 2019; Leff et al., 2015). However, the role of

11 potassium in bacterial colonization is less well explored. Our analysis suggests that addition of

12 potassium is a simple method to enhance bacilli colonization. Many bacilli species exert positive

13 effects on their plant host by enhancing plant growth, and inhibiting pathogens. An example is our

14 preliminary result that suggests that adding potassium could enhance the ability of B. valezensis to

15 protect seedlings from $R$. solani infection. 


\section{Materials and methods}

2

\section{Bacterial strains and growth conditions}

4 WT B. subtilis NCBI3610 and AR16 (Rosenberg et al., 2012) (B. subtilis PY79) were kindly 5 provided by Prof. Sigal Ben-Yehuda (Hebrew University) $\Delta$ tagE (BKK35730), $\Delta k t r A$ 6 (BKK31090), $4 k \operatorname{trC}$ (BKK14510), $\Delta$ kimA (BKK04320), (all in B. subtilis 168) were purchased

7 from the Bacillus genetic stock center (http://www.bgsc.org/). Genomic DNA was extracted from

8 AR16 and mutant strains using Wizard Genomic DNA Purification Kit (Promega) and transformed

9 into B. subtilis NCBI3610. The media and growth conditions used for DNA transformation of $B$.

10 subtilis NCBI3610 $\quad$ were $\quad$ described

11 http://2013.igem.org/Team:Groningen/protocols/Transformation. The bacteria were cultivated

12 routinely on Luria broth (LB) medium. When needed, the medium was solidified with $1.5 \%$ agar.

13 For biofilm formation, bacteria grown overnight were inoculated into MSgg medium and

14 incubated without shaking for 2 days at $30^{\circ}$ as described in (Branda et al., 2001). This medium

15 was also solidified with $1.5 \%$ agar.

\section{Phage strains and infection conditions}

17 SPO1 (1P4) and SPP1 (1P7) phage were purchased from the Bacillus genetic stock center. Phage

18 lysate was routinely prepared by adding approximately $10^{9}$ phage to mid-log cells grown in LB

19 medium supplemented with $10 \mathrm{mM} \mathrm{MgSO}_{4}$, until the culture was completely cleared. The lysate

20 was then filtered through a $0.22 \mu \mathrm{m}$ Millipore filter. For lysis dynamics in LB medium (Figure 2E

21 and Figure S1B), approximately $10^{9}$ phage were added to mid-log growing cells at multiplicity of

22 infection $\mathrm{MOI}=1$, and $\mathrm{OD}_{600}$ was monitored at 30 min intervals. For SPO1 infection in pellicle

23 biofilm (Figure S3), bacteria grown overnight were inoculated into MSgg medium, and phage 
1 added to $\mathrm{MOI}=1$. Bacteria were incubated without shaking for 2 days at $30^{\circ}$, and the number of

2 cultures with surviving cells was counted by eye. For SPO1 infection in solid biofilm (Figure 4)

3 bacteria grown overnight were inoculated into MSgg medium supplemented with $10^{5} \mathrm{PFU}$ (plaque

4 forming units), solidified with $1.6 \%$ agar. A spot of $5 \mu \mathrm{L}$ from the bacterial culture was inoculated

5 onto the plate and incubated for 2 days at $30^{\circ}$. Plates were scanned and colony diameter determined

6 using Image J

7 Monitoring bacterial growth and phage infection on plant roots.

8 Plants were grown on 0.5 MS media containing 1.1 gr Murashige and Skoog basal salts (in $500 \mathrm{ml}$

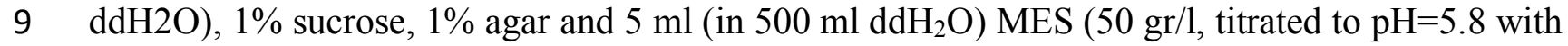

$10 \mathrm{NaOH}$ ). Plants were stratified for $2 \mathrm{~d}$ in a $4{ }^{\circ} \mathrm{C}$ dark room and grown vertically for 4-10 days under

11 long-day light conditions. Bacteria from fresh colonies were grown in LB medium to an $\mathrm{OD}_{600}=$

$12 \quad 1.0$ and then diluted 1:100 in PBSx1 for CFU measurements and microscopy, yielding

13 approximately $1 \times 10^{6}$. Phage were added to the PBSx1 at MOI $=0.1$, unless otherwise indicated.

14 Six-day old seedlings were transferred onto square Petri dishes containing 0.5 MS but without

15 sucrose. $2 \mu \mathrm{L}$ of bacterial dilution were deposited immediately above the root tip and left to dry for

$162 \mathrm{~min}$. The square plates were kept in a vertical position during the incubation time at $22^{\circ} \mathrm{C}$ under

17 long-day light conditions (16 h light/8 h darkness) in a plant growth chamber. For bacterial CFU

18 counting and microscopy, plants were incubated with bacteria for $48 \mathrm{hrs}$. Then the inoculated plant

19 roots were cut and washed three times in sterile water. For CFU counting the seedlings were

20 transferred to a tube with $1 \mathrm{ml}$ of PBSx1 and vortexed vigorously for 20 seconds, then a serial

21 dilution was plated on LB plates.

\section{Microscopy}


1 Roots were observed using a Zeiss LSM 880 laser scanning confocal microscope with $20 \mathrm{x}$

2 objective. conA488 staining (ThermoFisher C11252) was performed as described previously

3 (Habusha et al., 2019). Bacteria were observed using a Zeiss LSM 880 laser scanning confocal

4 microscope with $40 \mathrm{x}$ (water immersion) objective. Fluorescent intensity was measured using

$5 \quad$ ImageJ.

\section{DNA sequence analysis}

7 DNA was extracted from an overnight culture of the mutant bacterial strain along with the WT

8 strain using DNeasy PowerSoil Pro kit (QIAGEN), according to manufacturer's instructions.

9 DNA-seq libraries were prepared using Nextra DNA Flex library preparation kit (Illumina),

10 according to manufacturer's instructions. Illumina NextSeq 500 High-Output 50bp single reads

11 were partially assembled into contigs using the SPAdes algorithm (Bankevich et al., 2012) with

12 default parameters. The contigs were aligned to the genome of the WT bacteria from our lab stock.

13 DNA-seq dataset is available in the SRA repository with the accession numbers PRJNA729435

15 Graphs and Statistics

16 All graphs and statistical tests were performed in Excel. P values throughout the paper were 17 determined using Student t-test, except for figure S3, where a chi-square test was performed. 
bioRxiv preprint doi: https://doi.org/10.1101/2021.05.12.443821; this version posted May 12, 2021. The copyright holder for this preprint (which

was not certified by peer review) is the author/funder, who has granted bioRxiv a license to display the preprint in perpetuity. It is made available under aCC-BY-NC-ND 4.0 International license.

1

\section{Supplementary figures}

Figure S1

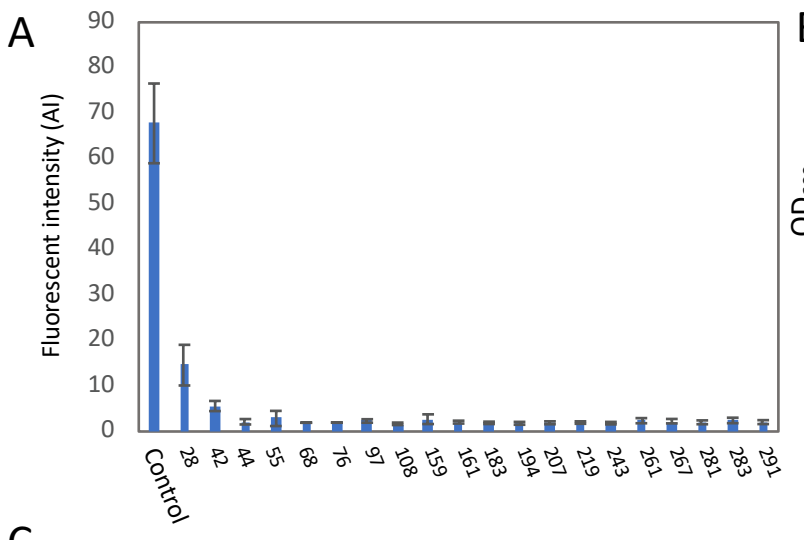

C
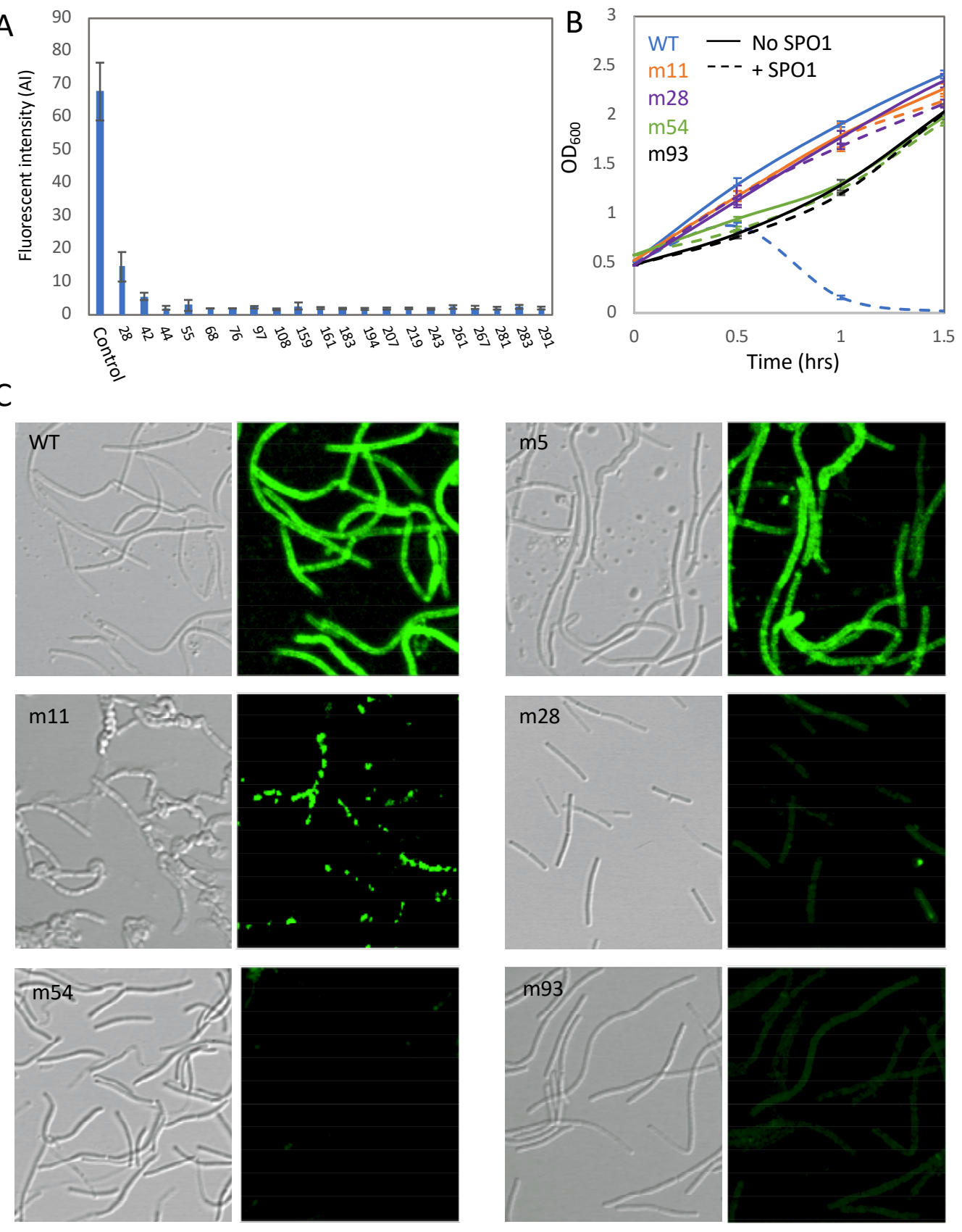
2 Figure S1. SPO1 resistance profile of phage survival isolates.

3 (A) SPO1 resistant bacteria isolated from plants were stained with con $\mathrm{A}_{488}$ and observed under the microscope. Shown

4 are average and SD fluorescent intensity values of 10 bacteria from each of the survived colonies.

5 (B) The indicated bacterial strains were infected with SPO1 in LB media and $\mathrm{OD}_{600}$ was followed. Shown are averages

6 and SD with $\mathrm{n}=3$.

7 (C) The indicated bacterial strains were stained with ConA 488 . Shown are representative DIC (left panels) and 8 fluorescence from $\mathrm{ConA}_{488}$ (right panels) images from each strain.

\section{Figure S2}
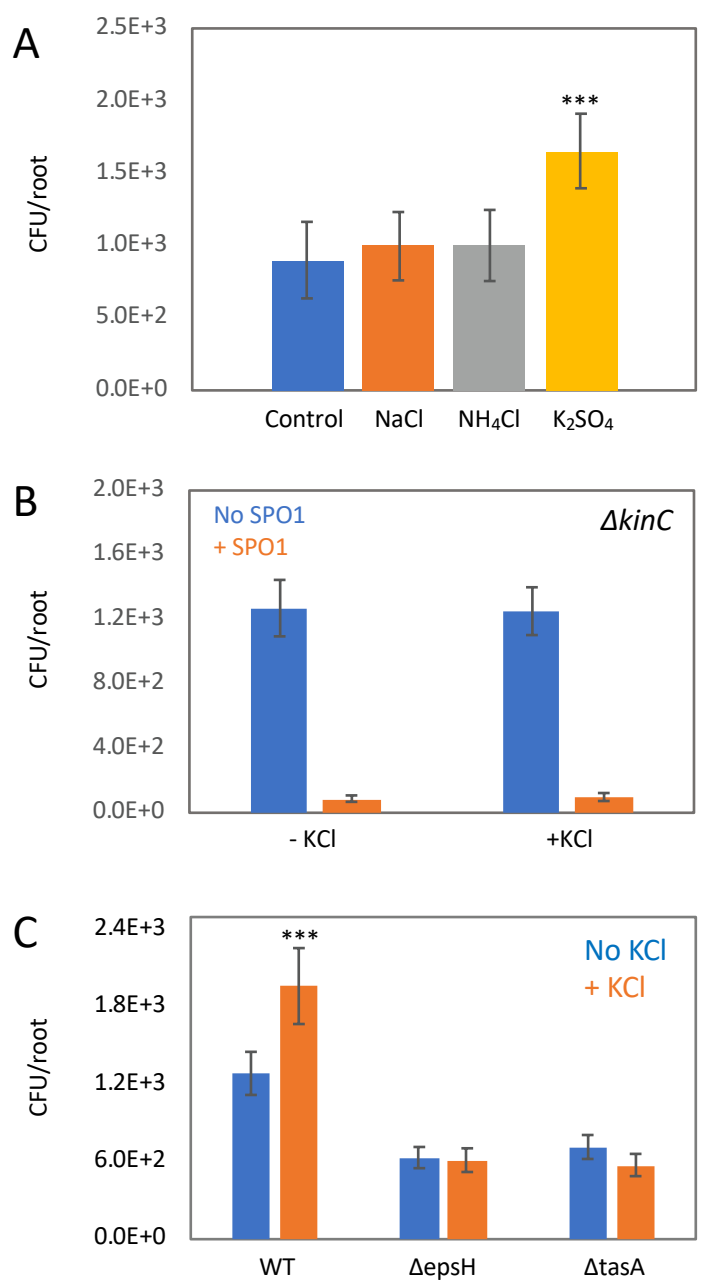


\section{Figure S2. Potassium modulates B. subtillis root colonization and phage resistance.}

2 (A) Seedlings were inoculated with WT bacteria and grown for $48 \mathrm{hrs}$ on $0.25 \mathrm{MS}$ agar plates, in the absence or

3 presence of $5 \mathrm{mM}$ of the indicated salts, and the number of colonizing bacteria were counted. Shown are averages and

$4 \quad \mathrm{SD}$ of 2 independent experiments with $\mathrm{n} \geq 3$ for each. $* * *=P<0.005$.

5 (B) Seedlings were inoculated with $\triangle \mathrm{kinC}$ bacteria, with or without SPO1 addition, and grown for $48 \mathrm{hrs}$ on $0.25 \mathrm{MS}$

6 agar plates, in the presence or absence of $5 \mathrm{mM} \mathrm{KCl}$, and the number of colonizing bacteria were counted. Shown are

7 averages and SD of 2 independent experiments with $\mathrm{n} \geq 3$ for each.

8 (C) Seedlings were inoculated with the indicated bacterial strains and grown for $48 \mathrm{hrs}$ on $0.25 \mathrm{MS}$ agar plates, in the

9 absence or presence of $5 \mathrm{mM} \mathrm{KCl}$, and the number of colonizing bacteria were counted. Shown are averages and SD

10 of 2 independent experiments with $\mathrm{n} \geq 3$ for each. $* * *=P<0.005$.

11

Figure S3
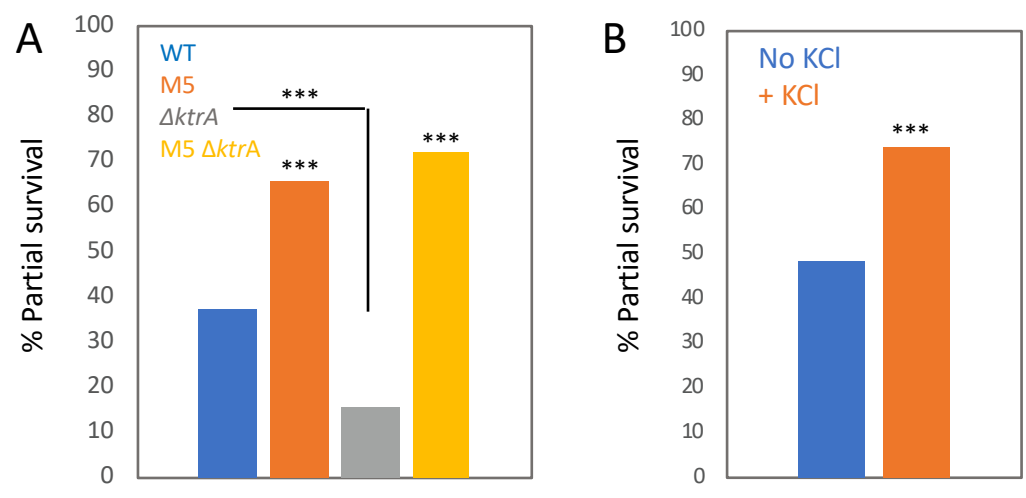

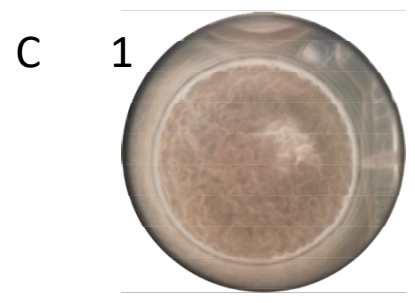

Non-infected

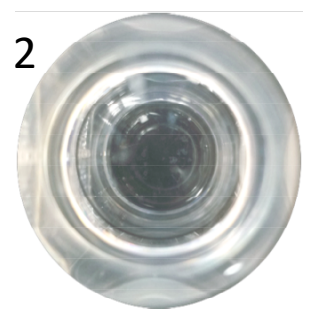

Complete lysis

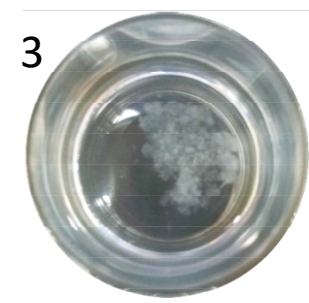

Partial survival 
bioRxiv preprint doi: https://doi.org/10.1101/2021.05.12.443821; this version posted May 12, 2021. The copyright holder for this preprint (which

was not certified by peer review) is the author/funder, who has granted bioRxiv a license to display the preprint in perpetuity. It is made available under aCC-BY-NC-ND 4.0 International license.

\section{Figure S3. Potassium modulates phage resistance during pellicle biofilm formation.}

2 (A) The indicated bacterial strains were inoculated into MSgg medium with or without SPO1 addition for 48 hrs, and

3 the number of cultures exhibiting partial SPO1 survival (see C) were counted. Shown is the percentage of the culture

4 surviving $\mathrm{SPO} 1, \mathrm{n} \geq 30 . * * *=P<0.005$.

5 (A) WT bacteria were inoculated into MSgg medium with or without $5 \mathrm{mM} \mathrm{KCl}$ and infected with SPO1 for 48 hrs,

6 as described in A. Shown is the percentage of the culture surviving SPO1, $\mathrm{n} \geq 30$. *** $=P<0.005$.

7 (C) Shown are representative images for the experiment described in (A and B), for an un-infected culture (1), a

8 culture undergoing complete phage lysis (2) and a culture counted as partially surviving phage infection (3). 


\section{References}

1. Allison, S.E., D'Elia, M.A., Arar, S., Monteiro, M.A., and Brown, E.D. (2011). Studies of the genetics, function, and kinetic mechanism of TagE, the wall teichoic acid glycosyltransferase in Bacillus subtilis 168. J Biol Chem 286, 23708-23716.

2. Amtmann, A., and Armengaud, P. (2009). Effects of N, P, K and S on metabolism: new knowledge gained from multi-level analysis. Curr Opin Plant Biol 12, 275-283.

3. Bais, H.P., Fall, R., and Vivanco, J.M. (2004). Biocontrol of Bacillus subtilis against infection of Arabidopsis roots by Pseudomonas syringae is facilitated by biofilm formation and surfactin production. Plant Physiol 134, 307-319.

4. Banda, J., Bellande, K., von Wangenheim, D., Goh, T., Guyomarc'h, S., Laplaze, L., and Bennett, M.J. (2019). Lateral Root Formation in Arabidopsis: A Well-Ordered LRexit. Trends Plant Sci 24, 826-839.

5. Bankevich, A., Nurk, S., Antipov, D., Gurevich, A.A., Dvorkin, M., Kulikov, A.S., Lesin, V.M., Nikolenko, S.I., Pham, S., Prjibelski, A.D., et al. (2012). SPAdes: a new genome assembly algorithm and its applications to single-cell sequencing. J Comput Biol 19, 455-477.

6. Beauregard, P.B., Chai, Y., Vlamakis, H., Losick, R., and Kolter, R. (2013). Bacillus subtilis biofilm induction by plant polysaccharides. Proc Natl Acad Sci U S A 110, E1621-1630.

7. Branda, S.S., Gonzalez-Pastor, J.E., Ben-Yehuda, S., Losick, R., and Kolter, R. (2001). Fruiting body formation by Bacillus subtilis. Proc Natl Acad Sci U S A 98, 11621-11626.

8. Brown, S., Santa Maria, J.P., Jr., and Walker, S. (2013). Wall teichoic acids of gram-positive bacteria. Annu Rev Microbiol 67, 313-336.

9. Buckling, A., and Brockhurst, M. (2012). Bacteria-virus coevolution. Adv Exp Med Biol 751, 347-370.

10. Buckling, A., and Rainey, P.B. (2002). The role of parasites in sympatric and allopatric host diversification. Nature 420, 496-499.

11. Castrillo, G., Teixeira, P.J., Paredes, S.H., Law, T.F., de Lorenzo, L., Feltcher, M.E., Finkel, O.M., Breakfield, N.W., Mieczkowski, P., Jones, C.D., et al. (2017). Root microbiota drive direct integration of phosphate stress and immunity. Nature 543, 513-518.

12. Chen, Y., Cao, S., Chai, Y., Clardy, J., Kolter, R., Guo, J.H., and Losick, R. (2012). A Bacillus subtilis sensor kinase involved in triggering biofilm formation on the roots of tomato plants. Mol Microbiol 85, 418-430.

13. Corrigan, R.M., Campeotto, I., Jeganathan, T., Roelofs, K.G., Lee, V.T., and Grundling, A. (2013). Systematic identification of conserved bacterial c-di-AMP receptor proteins. Proc Natl Acad Sci U S A 110, 9084-9089.

14. Diaz-Munoz, S.L., and Koskella, B. (2014). Bacteria-phage interactions in natural environments. Adv Appl Microbiol 89, 135-183. 
15. Fan, B., Wang, C., Song, X., Ding, X., Wu, L., Wu, H., Gao, X., and Borriss, R. (2018). Bacillus velezensis FZB42 in 2018: The Gram-Positive Model Strain for Plant Growth Promotion and Biocontrol. Front Microbiol 9, 2491.

16. Finkel, O.M., Salas-Gonzalez, I., Castrillo, G., Conway, J.M., Law, T.F., Teixeira, P., Wilson, E.D., Fitzpatrick, C.R., Jones, C.D., and Dangl, J.L. (2020). A single bacterial genus maintains root growth in a complex microbiome. Nature 587, 103-108.

17. Finkel, O.M., Salas-Gonzalez, I., Castrillo, G., Spaepen, S., Law, T.F., Teixeira, P., Jones, C.D., and Dangl, J.L. (2019). The effects of soil phosphorus content on plant microbiota are driven by the plant phosphate starvation response. PLoS Biol 17, e3000534.

18. Grau, R.R., de Ona, P., Kunert, M., Lenini, C., Gallegos-Monterrosa, R., Mhatre, E., Vileta, D., Donato, V., Holscher, T., Boland, W., et al. (2015). A Duo of Potassium-Responsive Histidine Kinases Govern the Multicellular Destiny of Bacillus subtilis. mBio 6, e00581.

19. Gundlach, J., Herzberg, C., Kaever, V., Gunka, K., Hoffmann, T., Weiss, M., Gibhardt, J., Thurmer, A., Hertel, D., Daniel, R., et al. (2017). Control of potassium homeostasis is an essential function of the second messenger cyclic di-AMP in Bacillus subtilis. Sci Signal 10.

20. Gundlach, J., Kruger, L., Herzberg, C., Turdiev, A., Poehlein, A., Tascon, I., Weiss, M., Hertel, D., Daniel, R., Hanelt, I., et al. (2019). Sustained sensing in potassium homeostasis: Cyclic di-AMP controls potassium uptake by KimA at the levels of expression and activity. J Biol Chem 294, 9605-9614.

21. Haaber, J., Leisner, J.J., Cohn, M.T., Catalan-Moreno, A., Nielsen, J.B., Westh, H., Penades, J.R., and Ingmer, H. (2016). Bacterial viruses enable their host to acquire antibiotic resistance genes from neighbouring cells. Nat Commun 7, 13333.

22. Habusha, M., Tzipilevich, E., Fiyaksel, O., and Ben-Yehuda, S. (2019). A mutant bacteriophage evolved to infect resistant bacteria gained a broader host range. Mol Microbiol 111, 1463-1475.

23. Hacquard, S., Garrido-Oter, R., Gonzalez, A., Spaepen, S., Ackermann, G., Lebeis, S., McHardy, A.C., Dangl, J.L., Knight, R., Ley, R., et al. (2015). Microbiota and Host Nutrition across Plant and Animal Kingdoms. Cell Host Microbe 17, 603-616.

24. Hansen, M.F., Svenningsen, S.L., Roder, H.L., Middelboe, M., and Burmolle, M. (2019). Big Impact of the Tiny: Bacteriophage-Bacteria Interactions in Biofilms. Trends Microbiol 27, 739-752.

25. Hoet, P.P., Coene, M.M., and Cocito, C.G. (1992). Replication cycle of Bacillus subtilis hydroxymethyluracil-containing phages. Annu Rev Microbiol 46, 95-116.

26. Holtmann, G., Bakker, E.P., Uozumi, N., and Bremer, E. (2003). KtrAB and KtrCD: two K+ uptake systems in Bacillus subtilis and their role in adaptation to hypertonicity. J Bacteriol 185, 1289-1298.

27. Koskella, B., and Brockhurst, M.A. (2014). Bacteria-phage coevolution as a driver of ecological and evolutionary processes in microbial communities. FEMS Microbiol Rev 38, 916-931.

28. Koskella, B., and Taylor, T.B. (2018). Multifaceted Impacts of Bacteriophages in the Plant Microbiome. Annu Rev Phytopathol 56, 361-380. 
29. Krober, M., Wibberg, D., Grosch, R., Eikmeyer, F., Verwaaijen, B., Chowdhury, S.P., Hartmann, A., Puhler, A., and Schluter, A. (2014). Effect of the strain Bacillus amyloliquefaciens FZB42 on the microbial community in the rhizosphere of lettuce under field conditions analyzed by whole metagenome sequencing. Front Microbiol 5, 252.

30. Labrie, S.J., Samson, J.E., and Moineau, S. (2010). Bacteriophage resistance mechanisms. Nat Rev Microbiol 8, 317-327.

31. Leff, J.W., Jones, S.E., Prober, S.M., Barberan, A., Borer, E.T., Firn, J.L., Harpole, W.S., Hobbie, S.E., Hofmockel, K.S., Knops, J.M., et al. (2015). Consistent responses of soil microbial communities to elevated nutrient inputs in grasslands across the globe. Proc Natl Acad Sci U S A 112, 10967-10972.

32. Lopez, D., Fischbach, M.A., Chu, F., Losick, R., and Kolter, R. (2009). Structurally diverse natural products that cause potassium leakage trigger multicellularity in Bacillus subtilis. Proc Natl Acad Sci U S A 106, 280-285.

33. Lugtenberg, B., and Kamilova, F. (2009). Plant-growth-promoting rhizobacteria. Annu Rev Microbiol 63, 541-556.

34. Lundberg, D.S., Lebeis, S.L., Paredes, S.H., Yourstone, S., Gehring, J., Malfatti, S., Tremblay, J., Engelbrektson, A., Kunin, V., Del Rio, T.G., et al. (2012). Defining the core Arabidopsis thaliana root microbiome. Nature 488, 86-90.

35. Moller, A.G., Lindsay, J.A., and Read, T.D. (2019). Determinants of Phage Host Range in Staphylococcus Species. Appl Environ Microbiol 85.

36. Pal, C., Macia, M.D., Oliver, A., Schachar, I., and Buckling, A. (2007). Coevolution with viruses drives the evolution of bacterial mutation rates. Nature 450, 1079-1081.

37. Paul, J.H., and Sullivan, M.B. (2005). Marine phage genomics: what have we learned? Curr Opin Biotechnol 16, 299-307.

38. Peiffer, J.A., Spor, A., Koren, O., Jin, Z., Tringe, S.G., Dangl, J.L., Buckler, E.S., and Ley, R.E. (2013). Diversity and heritability of the maize rhizosphere microbiome under field conditions. Proc Natl Acad Sci U S A 110, 6548-6553.

39. Pratama, A.A., and van Elsas, J.D. (2018). The 'Neglected' Soil Virome - Potential Role and Impact. Trends Microbiol 26, 649-662.

40. Rocha, R., Teixeira-Duarte, C.M., Jorge, J.M.P., and Morais-Cabral, J.H. (2019). Characterization of the molecular properties of KtrC, a second RCK domain that regulates a Ktr channel in Bacillus subtilis. J Struct Biol 205, 34-43.

41. Rodriguez-Valera, F., Martin-Cuadrado, A.B., Rodriguez-Brito, B., Pasic, L., Thingstad, T.F., Rohwer, F., and Mira, A. (2009). Explaining microbial population genomics through phage predation. Nat Rev Microbiol 7, 828-836.

42. Rosenberg, A., Sinai, L., Smith, Y., and Ben-Yehuda, S. (2012). Dynamic expression of the translational machinery during Bacillus subtilis life cycle at a single cell level. PLoS One 7, e41921.

43. Salmond, G.P., and Fineran, P.C. (2015). A century of the phage: past, present and future. Nat Rev Microbiol 13, 777-786. 
44. Shkoporov, A.N., and Hill, C. (2019). Bacteriophages of the Human Gut: The "Known Unknown" of the Microbiome. Cell Host Microbe 25, 195-209.

45. Stewart, C.R., Casjens, S.R., Cresawn, S.G., Houtz, J.M., Smith, A.L., Ford, M.E., Peebles, C.L., Hatfull, G.F., Hendrix, R.W., Huang, W.M., et al. (2009). The genome of Bacillus subtilis bacteriophage SPO1. J Mol Biol 388, 48-70.

46. Sustr, M., Soukup, A., and Tylova, E. (2019). Potassium in Root Growth and Development. Plants (Basel) 8.

47. Verbon, E.H., and Liberman, L.M. (2016). Beneficial Microbes Affect Endogenous Mechanisms Controlling Root Development. Trends Plant Sci 21, 218-229.

48. Vidakovic, L., Singh, P.K., Hartmann, R., Nadell, C.D., and Drescher, K. (2018). Dynamic biofilm architecture confers individual and collective mechanisms of viral protection. Nat Microbiol 3, 26-31.

49. Vlamakis, H., Chai, Y., Beauregard, P., Losick, R., and Kolter, R. (2013). Sticking together: building a biofilm the Bacillus subtilis way. Nat Rev Microbiol 11, 157-168.

50. Wagner, M.R., Lundberg, D.S., Del Rio, T.G., Tringe, S.G., Dangl, J.L., and Mitchell-Olds, T. (2016). Host genotype and age shape the leaf and root microbiomes of a wild perennial plant. Nat Commun 7, 12151.

51. Westra, E.R., van Houte, S., Oyesiku-Blakemore, S., Makin, B., Broniewski, J.M., Best, A., Bondy-Denomy, J., Davidson, A., Boots, M., and Buckling, A. (2015). Parasite Exposure Drives Selective Evolution of Constitutive versus Inducible Defense. Curr Biol 25, 10431049.

52. Winstel, V., Kuhner, P., Salomon, F., Larsen, J., Skov, R., Hoffmann, W., Peschel, A., and Weidenmaier, C. (2015). Wall Teichoic Acid Glycosylation Governs Staphylococcus aureus Nasal Colonization. mBio 6, e00632.

25 